\title{
Improving Early Cancer Detection Knowledge through Mobile Learning Application
}

\author{
https://doi.org/10.3991/ijoe.v15i02.9678
}

\author{
Hery Harjono Muljo, Anzaludin Samsinga Perbangsa, Yulius, Bens Pardamean $\left({ }^{\varpi}\right)$ \\ Bina Nusantara University, Jakarta, Indonesia \\ bpardamean@binus . edu
}

\begin{abstract}
The study aims to build a mobile-based application prototype with an Android platform for learning early cancer detection. This prototype design is emerged from data collection about the challenges faced by health workers to gain knowledge about cancer. It requires mobile-based learning technology to assist in their daily work. Based on the data gathered, an Android-based application is developed to be used to simplify the knowledge dissemination method and enhance the material quality by digitizing content into multimedia formats.
\end{abstract}

Keywords-Mobile learning, prototype, Android, early detection, cancer

\section{Introduction}

Current technological developments are so rapid and have penetrated all aspects of life, especially information and communication technology (ICT) in Indonesia. In June 2017, around 132 million Indonesians have used and utilized the Internet with a penetration rate of $50 \%$, and around 126 million are active users of social media [1]. This reflects the form of technology acceptance and utilization among the Indonesian people. Meanwhile, the total population of mobile device users reached 177.9 million users, with a penetration rate of $67 \%$, and around $67.5 \%$ of them were active mobile social users. Owners of mobile devices in Indonesia spend at least 3 hours and 10 minutes every day to access the Internet via mobile phones [2].

The use of the operating system on mobile phones in Indonesia is dominated by the Android operating system developed by Google by $74.2 \%$ at the end of 2015 [3]. Android dominance is supported by the presence of various brands of smartphones with various price ranges that use this operating system. The price factor is one of the factors considered by consumers in buying mobile phones [4]. Prices vary from 7 mobile phones with Android operating systems to support elements in reaching all levels of society.

The learning process in Indonesia generally uses physical teaching tools such as textbooks. Books that are in physical form are often affected by problems such as paper, distribution, and logistics. The Indonesian Ministry of Research, Technology and Higher Education also promotes electronic-based learning tools to overcome 
these obstacles [5]. The adoption of technology, especially smartphones to promote the knowledge dissemination method is recognized as mobile learning or m-learning [6]. This mobile-based learning has the advantage that material or instructional material can be accessed anytime and anywhere, which allows students to participate in activities in place and time constraints [7]. Mobile-based learning also has the capacity to increase learning motivation through participation in collaborative learning by stimulating students through a sense of ownership of the content of active participation in various social, collaborative and cooperative activities that are all carried out from mobile devices [8]. One of the obstacles faced in the implementation of teaching in the health sector is the high cost [9].

One of the advantages of using mobile learning technology is that it can reduce costs to a lower level so that it has a positive impact on health education [10]. The implementation of mobile learning to improve health knowledge is still relatively new and has the potential to be further developed. With all its advantages, mobile learning applications in developing countries give a positive effect on promoting knowledge in the health area [11].

The rapid development of mobile technology is utilized by medical personnel for the needs of health education practices [12],[13] which is the extension of online learning, particularly in the early detection of cancer [14]. Some preliminary studies even show that the advanced use of mobile in the world of health can act as a tool for detection or diagnosis [15]. The use of mobile devices as cancer detection aids is effectively applied to overcome the constraints of distance in areas that are difficult to reach [16]. In the study applied to active health workers regarding simple mobile learning applications related to early detection of short message service (SMS) breast cancer showed a significant increase in test results after the learning process [17].

Mobile applications for online learning about early detection of breast cancer in Indonesia are emerging along with the campaign for breast cancer awareness, as well as the establishment of October as "Breast Cancer Awareness Month". Pita Pink is a mobile application for breast cancer early detection for iOS and Android-based platform that is widely used in Indonesia. The application that is also popular is Love Pink Breasties presented by Love Pink Indonesia Community [18].

\section{$2 \quad$ Literature Review and Related Work}

\subsection{Mobile Learning}

Mobile learning encourages technology, student, and learning mobility [19] by utilizing mobile technology [20] conducted through portable handheld electronic devices [21] and is an intelligent technology [22].

In facing the challenges of the world of education, mobile learning is one solution, because it can be increased options for the personalization of learning and provide many opportunities, both for formal and informal learning [23]. In addition, it is a powerful method for attracting learning participants and enhancing the learning experience due to the quality of mobility and supporting platforms [24]. 
The main benefit of mobile learning is that it can access content anytime, anywhere, and can enhance student-centered learning, as well as reduce cultural barriers and communication between faculty and students [6]. Its presence can be an opportunity to change existing learning strategies to give students a flexible approach [25] and facilitate collaboration between students and instructors through asynchronous and synchronous communication techniques [26]. One thing that is no less interesting, mobile learning provides benefits for learners, namely being able to enjoy freedom and independence [27].

\subsection{Shih's Mobile Learning Model}

The aspects to recognize when implementing m-learning are the opportunities to present novel learning, enabling adaptation to differences in user learning styles, the impact of interactions in the community, and the influence of changes or improvements in technology [28]. Other important aspects that must be considered are how users acquire knowledge and how study activities conducted. Based on these aspects, the mobile learning model is described in figure 1.

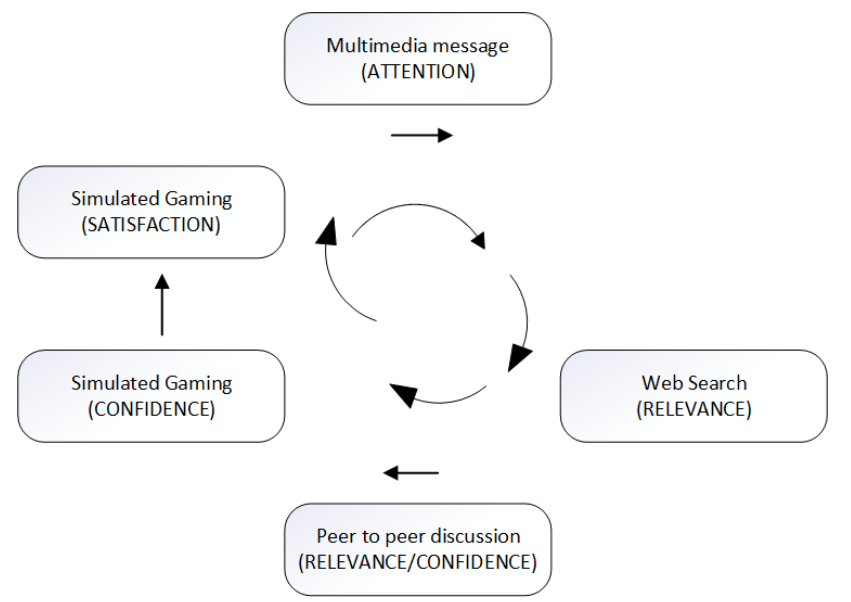

Fig. 1. Shih's M-Learning Model [26]

The Shih's mobile learning model is presented to promote the learning design for m-learning modification of the Keller ARCS (Attention, Relevance, Confidence, and Satisfaction) motivation model [29].

\subsection{CMM: LTCS Model}

Location, Technology, Culture and Satisfaction (LTCS) is a comprehensive and innovative m-Learning design model to design and build new learning platforms and to adapt learning materials/resources for global audiences [30] This model combines the Keller's (1983) ARCS model [29] and Shih's mobile learning model [28]. 


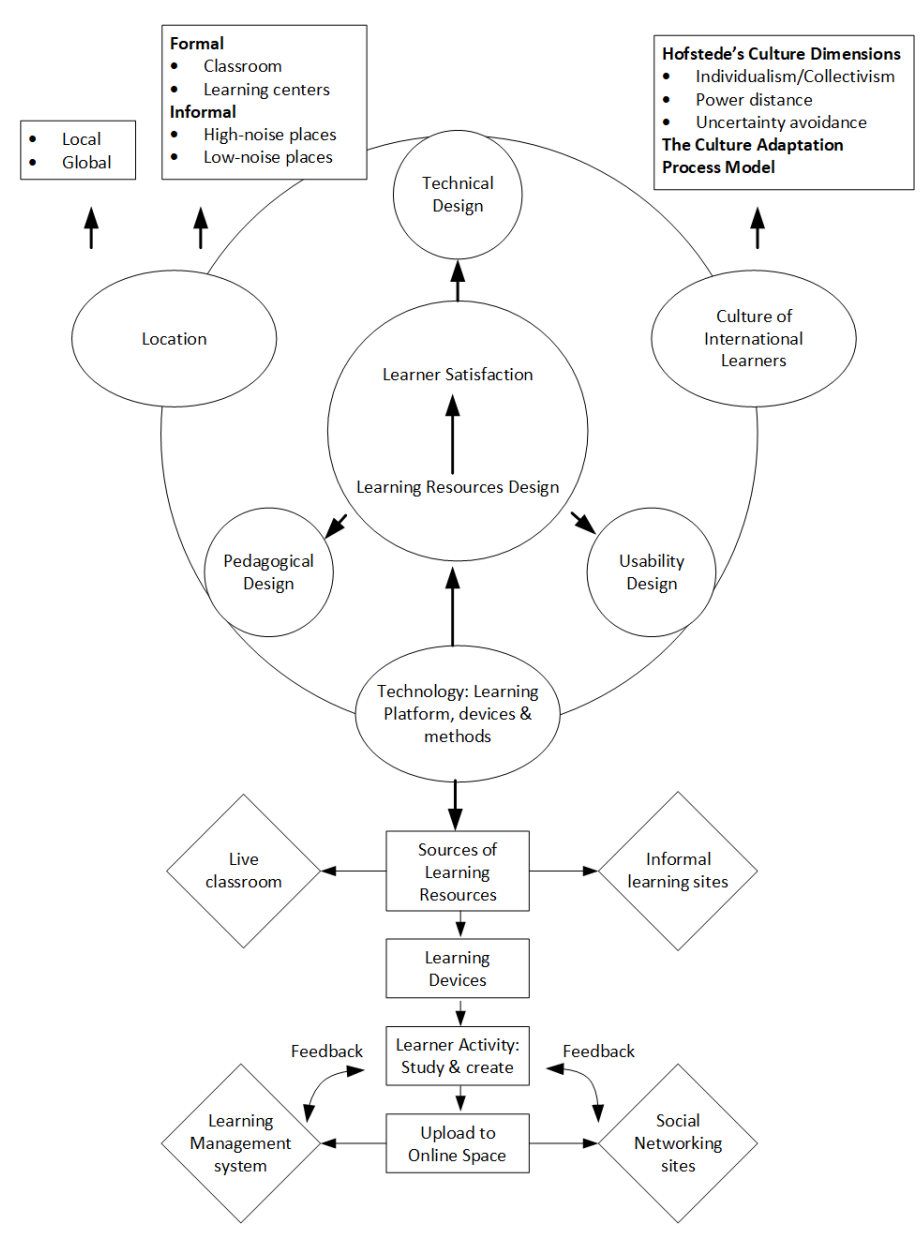

Fig. 2. Location, Technology, Culture, and Satisfaction (LTCS) Model [30]

\section{Method and Materials}

This study developed mobile learning prototype for early detection cancer using study literature and the ADDIE (Analysis, Design, Development, Implementation, Evaluation) method.

\subsection{Instructional Design}

An instructional design methodology used to design a learning system for early detection of cancer using the ADDIE framework model includes [31]:

- Analysis: The analysis phase is the phase of analyzing student data (competencies, preferences and user needs), elaborating instructional analysis (identifying the ac- 
tions needed to study and applying current knowledge in a direction), delivering effective instructional goals (which are meant to define desired outcomes and measure the accomplishment of the goal).

- Design: The design stage is intended to facilitate learners interaction with the material provided, choose the appropriate course format, and compose a strategy by blending many techniques to improve comprehension of the topic. This stage also clarifies the purpose of the course so that behavior and results can be observed and measured.

- Development: This phase integrates technology by regulating the educational process, making factual examples that are suitable in the material, identifying content that needs to be revised, and evaluating all content created.

- Implementation: Intensify products by analyzing, redesigning, and enhancing mobile-based learning applications so that mobile-based learning application products are effective.

- Evaluation: The final process in the ADDIE model is the Evaluation phase. This phase evaluates each step to ensure that all objectives are met and meet the needs of the user. The thing that must be considered in the evaluation stage is that respondents must be anonymous so that the results are objective and can be used to improve instructional design and goals

\section{$4 \quad$ Result and Discussion}

\subsection{Architecture}

This application is built using the Android programming language and can interact with a database server with a web service using JSON. The database server used is MySQL which can be accessed by web services with APIs using PHP web-scripts. This mobile learning is used by health worker and is connected to a web-based application used by administrators and content specialist. The architecture is shown in figure 3 .

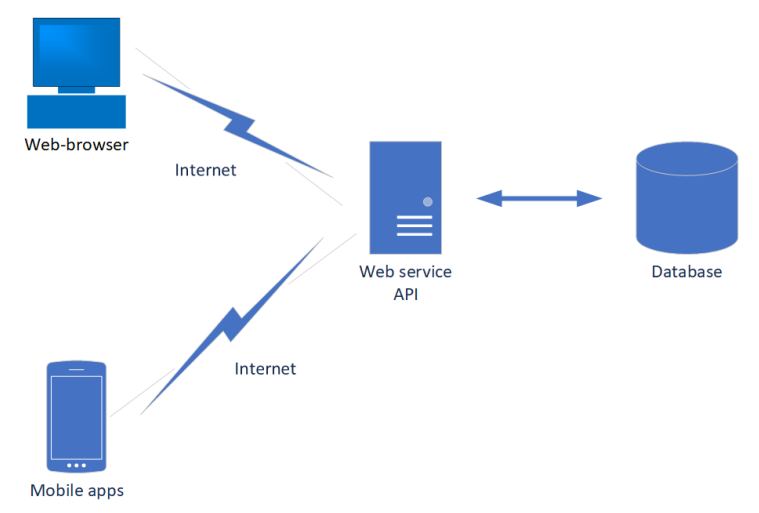

Fig. 3. System Architecture 
The workflows are shown in figure 4. First, the administrator creates a course, which is a particular field of science that is divided into a set of classes and topics consisting of material and related questions. The course is then made up of topics, learning content, and questions about the answer to test by specialist content. The administrator then creates a class by specifying the start schedule and completion schedule. Students who want to take part in learning must register first through mobile apps. After registering and choosing courses and classes, participants must take a pretest before downloading learning materials. Then participants can discuss with the subject content specialist and other students through the forum. Finally, the student must complete the post-test before being able to download the graduation certificate.

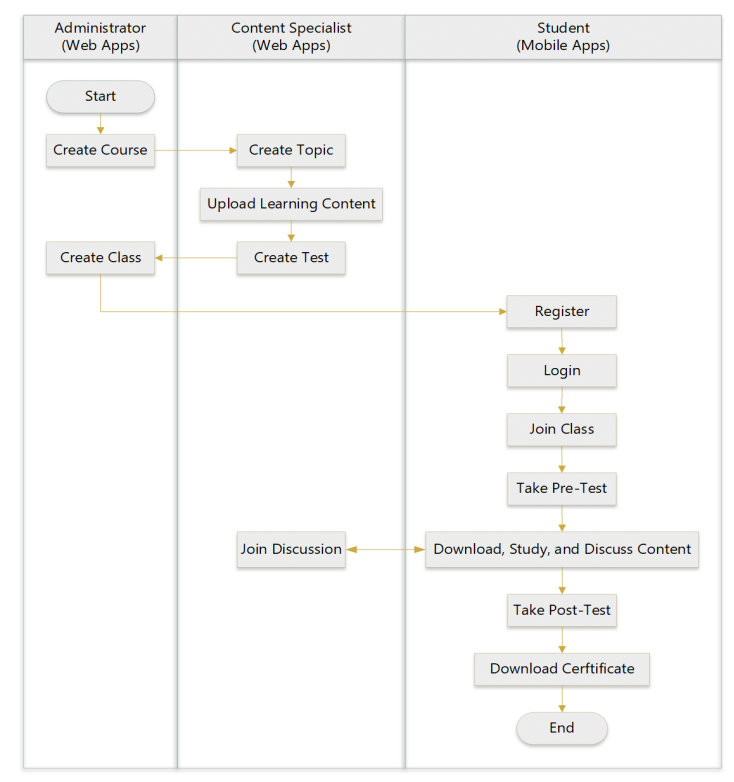

Fig. 4. System Workflow

\subsection{The Database}

The application operates a relational database for data storage and management. MySQL database management system (DBMS) is chosen because it is open source software and is known for its security, scalability, and has an active developer community.

\subsection{Navigation and User Interface}

This application consists of 12 pages consisting of splash screen, log in, signup, forget password, home, score, certificate, course, topic, news, rules, and forum. The navigation diagram of mobile learning prototype for early detection cancer is shown in figure 5. 


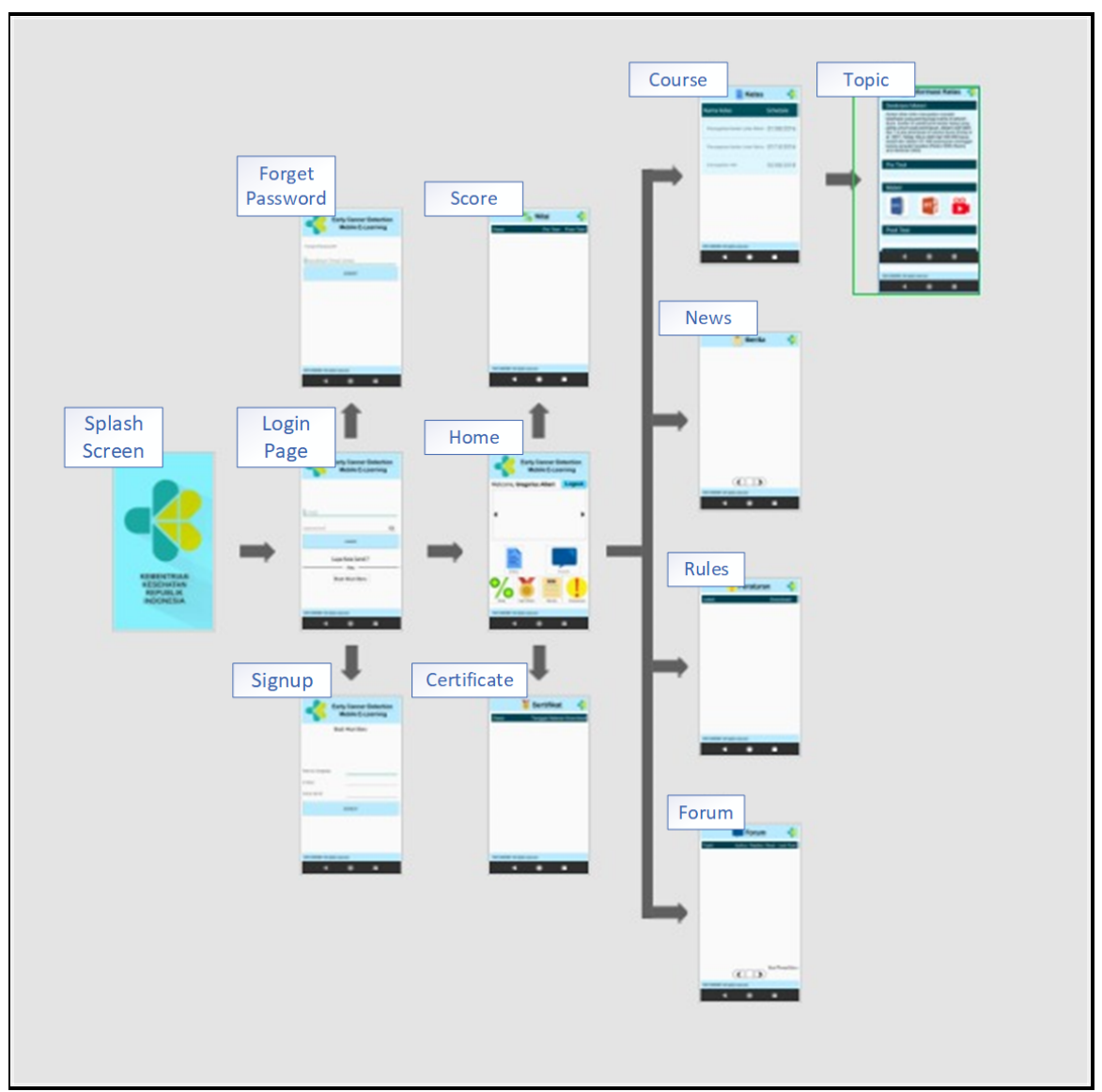

Fig. 5. Navigation Diagram

Splash screen appears a few seconds after the user opens an application that shows the application logo before the smartphone loads the login page. Users must register before entering the home page. Users who forget the password can reset it in the forget password page. After logging in, the user enters the home page which consists of a menu to the course page, news, rules, and forums (see figure 6). There is also a slideshow on the login page to show important announcements. The course page shows a list of courses that can be followed. If the user clicks on a course, they will enter the course details and can start the pre-test as a condition for entering the first learning content. The news page shows the announcement list, while the rules page shows a list of rules for participating in learning. The forum page lists threads of discussion between participants and content specialist. Users who have completed and passed the post-test can download certificate in pdf file format and can print it (see figure 7). 


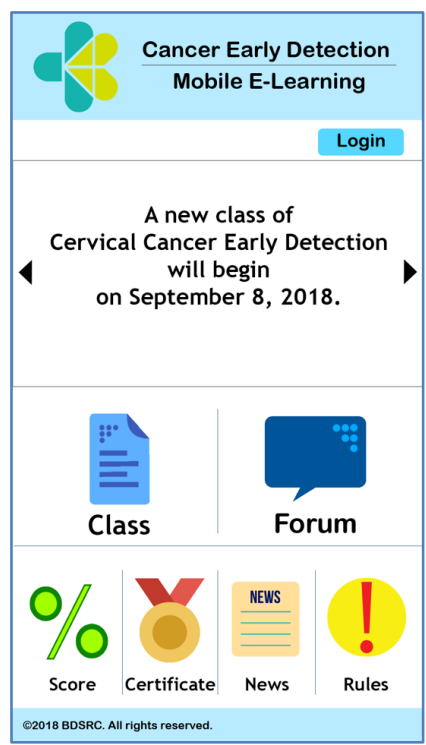

Fig. 6. User Interface of the Home Page

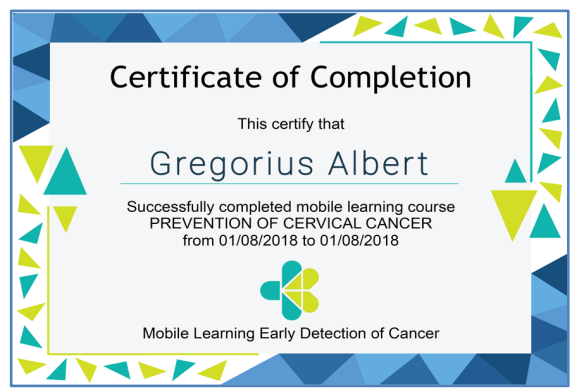

Fig. 7. Certificate of Completion

\section{Conclusion}

This application is developed to fulfill the purpose of building a mobile learning prototype for the dissemination of knowledge of early detection of cancer using the ADDIE method. This system can be used according to its function and meet the needs of smartphone users, especially health workers to support work.

\section{Acknowledgement}

Sincere gratitude to the Indonesian Directorate of Research and Community Service, Ministry of Research, Technology, and Education for providing the funding needed to complete this study through the Applied Product Research Grant program. 
Thank you to Christopher Andrew, Gregorius Albert, and Bernard Wijaya for technical assistance in programming and design.

\section{$7 \quad$ References}

[1] Aspan, H., \& Aryza, S. (2018). Effect Perspective Law in Case Social Media Indonesia, 23(1), 27-30. https://doi.org/10.9790/0837-2301022730

[2] Sidik, F. (2018, February 1). Pengguna Perangkat Mobile di Indonesia Semakin Tinggi, Ini Datanya! (Bisnis Indonesia) Retrieved Agustus 6, 2018, from http://industri.bisnis.com/read/20180201/101/733037/javascript

[3] Statista. (2015). Market share held by mobile operating systems in Indonesia from January 2012 to December 2015. Retrieved April 19, 2016, from statista: http://www.statista.com/statistics/262205/market-share-held-by-mobile-operating-systemsin20indonesia/

[4] Uddin, M. R., Lopa, N. Z., \& Oheduzzaman, M. (2014). Factors Affecting Customers' Buying Decisions of Mobile Phone: a Study on Khulna City, Bangladesh. International Journal of Managing Value \& Supply Chains, 5(2), 21-28. https://doi.org/10.51 21/ijmvsc.2014.5203

[5] Kemendikbud. (2015). E-Sabak, Pembelajaran Kreatif di Era Digital. Retrieved August 26, 2018, from https://www.kemdikbud.go.id/main/blog/2015/01/e-sabak-pembelajarankreatif-di-era-digital-3757-3757-3757

[6] Sarrab, M., Elgamel, L., \& Aldabbas, H. (2012). Mobile learning (m-learning) and educational environments. International journal of distributed and parallel systems, 3(4), 31. https://doi.org/10.5121/ijdps.2012.3404

[7] Ellaway, R. H., Fink, P., Graves, L., \& Campbell, A. (2014). Left to Their Own Devices: Medical Learners' Use of Mobile Technologies. Med Teach, 36(2), 130-138. https://doi.org/10.3109/0142159X.2013.849800

[8] El-Hussein, M. O. M., \& Cronje, J. C. (2010). Defining Mobile Learning in the Higher Education Landscape. Educational Technology \& Society, 13 (3), 12-21.

[9] Walsh, K., \& Jaye, P. (2013). Cost and Value in Medical Education. Educ Prim Care, 24(6), 391-393. https://doi.org/10.1080/14739879.2013.11494206

[10] Sandars, J. (2010). Cost Effectiveness in Medical Education. Abingdon: Radcliffe.

[11] Mohapatra, D. P., Mohapatra, M., Chittoria, R. K., Friji, M. T., \& Kumar, S. D. (2015). The Scope of Mobile Devices in Health Care and Medical. International Journal of Advanced Medical and Health Research, 2(1), 3-8. https://doi.org/10.4103/2349$\underline{4220.159113}$

[12] Dearnley, C., Haigh, J., \& Fairhall, J. (2008). Using Mobile Technologies for Assessment and Learning in Practice Settings: A Case Study. Nurse Education in Practice , 8 (3), 197204. https://doi.org/10.1016/j.nepr.2007.07.003

[13] Muljo, H. H., Perbangsa, A. S., \& Pardamean, B. (2018). Mobile Learning for Early Detection Cancer. International Journal of Interactive Mobile Technologies (IJIM), 12(2), 39-53. https://doi.org/10.3991/ijim.v12i2.7814

[14] Muljo, H. H., Pardamean, B., \& Perbangsa, A. S. (2017). The Implementation of Online Learning for Early Detection of Cervical Cancer. Journal of Computer Science, 13(11), 600-607. https://doi.org/10.3844/jcssp.2017.600.607

[15] Muhlestein, J. B., Le, V., Albert, D., Moreno, F., Anderson, J., Yanowitz, F., et al. (2015). Smartphone ECG for Evaluation of STEMI: Results of the ST. Leuis Pilot Study. J Electrocardiol, 48, 249-59. https://doi.org/10.1016/j.jelectrocard.2014.11.005 
[16] Swaddiwudhipong, W., Chaovakiratipong, C., Nguntra, P., Mahasakpan, P., Tatip, Y., \& Boonmak, C. (1999). A Mobile Unit: An Effective Service for Cervical Cancer Screening Among Rural Thai Women. International Journal of Epidemiology , 28 (1), 35-39. https://doi.org/10.1093/ije/28.1.35

[17] Alipour, S., Jannat, F., \& Hosseini, L. (2014). Teaching Breast Cancer Screening via Text Messages as Part of Continuing Education for Working Nurses: A Case-control Study. Asian Pac J Cancer Prev., 15 (14), 5607-5609. https://doi.org/10.7314/ APJCP.2014.15.14.5607

[18] Fajriana, M. (2015). Lovepink Breasties, Aplikasi Android Pendeteksi Kanker Payudara. Retrieved October 26, 2016, from https://www.liputan6.com/lifestyle/read/2336114/ lovepink-breasties-aplikasi-android-pendeteksi-kanker-payudara

[19] El-Hussein, M. O. M., \& Cronje, J. C. (2010). Defining Mobile Learning in the Higher Education Landscape. Educational Technology \& Society, 13 (3), 12-21.

[20] Doneva, R., Kasakliev, N., \& Totkov, G. (2007). Towards mobile university campuses. Communication and Cognition: Monographies, 40 (1-2), 67-75.

[21] Joan, D. R. (2013). A study on mobile learning as a learning style in modern research practice. I-Manager's Journal on School Educational Technology, 8(4), 29. https://doi.org/10.26634/jsch.8.4.2249

[22] Farley, H., Murphy, A., \& Rees, S. (2012). Revisiting the definition of Mobile Learning. In H. Carter, M. Gosper and J. Hedberg (Eds.), Electric Dreams. Proceedings ascilite 2013 Sydney. (pp.283-287).

[23] Mehdipour, Y., \& Zerehkafi, H. (2013). Mobile learning for education: Benefits and challenges. International Journal of Computational Engineering Research, 3(6), 93-101.

[24] Behera, S. K. (2013). E- and M-learning: A Comparative Study. International Journal on New Trends in Education and Their Implications, 4(3), 65-78.

[25] Alhajri, R. (2016). Prospects and Challenges of Mobile Learning Implementation: A Case Study. Journal of Information Technology \& Software Engineering, 6(5), 1-8. https://doi.org/10.4172/2165-7866.1000189

[26] Corbeil, J.R. and Valdes-Corbeil, M.E., “Are You Ready for Mobile Learning?”, Educause Quarterly, pp. 51-58, No. 2, 2007.

[27] Uden, L. (2007). Activity Theory for Designing Mobile Learning. Journal of Mobile Learning and Organisation, 1 (1), 81-102. https://doi.org/10.1504/IJMLO.2007.011190

[28] Shih, Y. E., \& Mills, D. (2007). Setting the New Standard with Mobile Computing in Online Learning. International Review of Research in Open and Distance Learning, 8(2), 1-16. https://doi.org/10.19173/irrodl.v8i2.361

[29] Keller, J. M., (1983). Development and Use of the ARCS Model of Motivational Design (Report No. IR 014 039). Enschede, Netherlands: Twente Univ. of Technology. (ERIC Document Reproduction Service No. ED 313 001)

[30] Wang, M., Callaghan, V., Singer, E., and Sun, H. (2016). Design Engaging Mobile Learning For The Global Audience. International Conference on Education in Mathematics, Science \& Technology. Volume 4, Pages 1-7.

[31] Aldoobie, N. (2015). ADDIE Model. American International Journal of Contemporary Research, 5(6), 68-72. https://doi.org/10.13140/2.1.4687.6169

\section{Authors}

Hery Harjono Muljo is a researcher at Bioinformatics \& Data Science Research Center and a lecturer at Accounting Program, Bina Nusantara University, Jakarta, 
Indonesia. His research expertise is in developing management information system of health institutions such as hospitals and clinics.

Anzaludin Samsinga Perbangsa is a researcher at Bioinformatics \& Data Science Research Center and a lecturer at School of Information Systems, Bina Nusantara University, Jakarta, Indonesia. His research expertise is in developing tools to investigate the interplay of genetic and environmental factors in agriculture and has developed agricultural germplasm database.

Yulius is a researcher at Bioinformatics \& Data Science Research Center and a lecturer at School of Information Systems, Jakarta, Indonesia. His current research interest is focused on developing tools and strategies with IT solution to face global IT trends.

Bens Pardamean is Director of Bioinformatics \& Data Science Research Center and Associate Professor of Computer Science, Bina Nusantara University, Jakarta, Indonesia. His research expertise is in information technology, bioinformatics, and education, including a strong background in database systems, computer networks, and quantitative research.

Article submitted 09 October 2018. Resubmitted 22 November 20187. Final acceptance 12 December 2018. Final version published as submitted by the authors. 